\title{
PENGARUH STRES KERJA DAN ROTASI KERJA TERHADAP KINERJA KARYAWAN PADA PT. ASTRA CREDIT COMPANIES CABANG PONDOK CABE TANGERANG SELATAN
}

\author{
Sam Cay, S.E., M.M. ${ }^{1}$, Okta Setyo Arbian ${ }^{2}$ \\ Staf Pengajar Fakultas Ekonomi Universitas Pamulang \\ Email: dosen02207@gmail.com
}

\begin{abstract}
ABSTRAK
Penelitian ini bertujuan untuk mengetahui dan menganalisis pengaruh stres kerja terhadap kinerja, mengetahui dan menganalisis pengaruh rotasi kerja terhadap kinerja karyawan PT. Astra Credit Companies Tangerang Selatan.

Metode penelitian yang digunakan oleh penulis adalah metode kuantitatif dengan pendekatan asosiatif, yang bertujuan untuk mengetahui pengaruh dua atau lebih variabel, dimana pendekatan ini memberikan deskripsi masalah untuk mencari efek antara X1 (stres kerja) dan X2 (rotasi kerja) dengan variabel Y ( Kinerja Karyawan) maka dilakukan uji hipotesis untuk menentukan apakah hipotesis yang diajukan diterima atau ditolak dengan analisis regresi. Tes yang digunakan untuk menguji instrumen penelitian adalah uji validitas dan reliabilitas. Pengujian hipotesis menggunakan uji-t (parsial), uji-F (secara bersamaan), analisis regresi linier berganda, koefisien korelasi, dan deteksi menggunakan perangkat lunak Windows SPSS 24.

Dari hasil uji regresi berganda, nilai konstan 18.298 menunjukkan bahwa jika variabel stres kerja (X1) dan rotasi kerja (X2) menurun, nilainya 0, maka kinerja karyawan (Y) adalah 18.298. Koefisien korelasi sebesar 0,647 berarti ada korelasi yang erat, nilainya harus $41,8 \%$. Variabel stres kerja sebagian memiliki efek negatif dan tidak signifikan pada kinerja karyawan dengan angka -1,870>t pada Tabel 1.671, menunjukkan bahwa Ho ditolak dan H1 diterima. Variabel rotasi pekerjaan secara parsial berpengaruh dan signifikan, diwakili oleh thitung 5,135>t pada Tabel 1.671 dengan nilai signifikan $0,000<0,05$. Ini menunjukkan bahwa Ho ditolak dan $\mathrm{H} 2$ diterima, yang berarti bahwa variabel Rotasi Kerja secara parsial mempengaruhi kinerja karyawan. Jadi, jika nilai Rotasi Kerja variabel meningkat, kinerja karyawan akan meningkat. Stres dan rotasi pekerjaan secara simultan memiliki dampak signifikan terhadap kinerja karyawan. Berdasarkan uji statistik F (simultan), dapat dilihat bahwa untuk Fhitung 22,307> nilai $F$ Tabel 3,15 dan nilai signifikan $0,000<0,05$ dapat disimpulkan bahwa Ho ditolak dan $\mathrm{H} 3$ diterima, yang berarti bahwa stres kerja dan rotasi kerja secara simultan berpengaruh signifikan terhadap Pegawai kinerja di PT. Perusahaan kredit Astra di Tangerang Selatan.
\end{abstract}

\section{Kata Kunci: Stres Kerja, Rotasi Kerja, Kinerja Karyawan.}

\section{ABSTRACT}

The purpose of this research is to find out and analyze the effect of work stress on employee performance, to know and analyze the effect of work rotation on 
employee performance, and to know and analyze the effect of work stress and job rotation simultaneously on employee performance at PT . Astra Credit Companies South Tangerang.

The research method used by the author is a quantitative method with an associative approach that aims to determine the effect of two or more variables, where this approach provides a description of the problem to look for the influence between the variables X1 (Job Stress) and variable X2 (Work Rotation) with Y variables ( Employee Performance) then hypothesis testing is performed to determine whether the proposed hypothesis is accepted or rejected using regression analysis. The test used to test the research instrument is a validity and reliability test. Hypothesis testing uses $\mathrm{t}$ test (partial), $\mathrm{F}$ test (simultaneous), multiple linear regression analysis, correlation coefficient and determination with the help of SPSS 24 for Windows Software.

From the results of the multiple regression test the constant value of 18.298 states that if there is a decrease in the variable Work Stress (X1) and Work Rotation (X2) the value is 0, then the Employee Performance (Y) is 18,298. Correlation coefficient value 0.647 means there is a strong relationship, the value of determination is $41.8 \%$. Work Stress Variable partially has a negative and not significant effect on Employee Performance with a tcount of -1.870>t table 1.671, this shows that Ho is rejected and H1 is accepted. Work Rotation variable partially influential and significant, this is indicated by the value of tcount 5.135 $>\mathrm{t}$ table 1.671 with a significant value of $0.000<0.05$. This shows that Ho is rejected and H2 is accepted, meaning that the Work Rotation variable partially influences Employee Performance. So, if the value of the variable Work Rotation rises, Employee Performance will increase. Job Stress and Job Rotation simultaneously have a significant effect on Employee Performance. Based on the statistical test $F$ (simultaneous), it can be seen that the value of Fcount 22.307> F table 3.15 and a significant value of $0.000<0.05$, it can be concluded that Ho is rejected and $\mathrm{H} 3$ is accepted, this means that Job Stress and Job Rotation simultaneously have a significant effect on Employee Performance at PT. Astra Credit Companies South Tangerang.

\section{Keywords: Job Stress, Job Rotation, Employee Performance.}

\section{PENNDAHULUAN \\ A. Latar Belakaang}

Perkembangan dunia bisnis yang berkembang, sejalan dengan kondisi ekonomi Indonesia, membutuhkan persaingan yang ketat, sebagai organisasi bisnis yang tujuan utamanya adalah memaksimalkan keuntungan (di antara misi lainnya), perusahaan harus siap bersaing.

Oleh karena itu, perusahaan harus memiliki manajemen yang efektif dan, tentu saja, karyawan sebagai aset utama perusahaan adalah faktor yang mendukungnya, di mana karyawan adalah aset terbesar di sebuah organisasi.

Dalam observasi dengan menggali informasi dari beberapa karyawan ditemukan adanya stress kerja yang dialami oleh karyawan PT Astra Credit Companies yang ditandai oleh perasaan karyawan yang memiliki peran berlebihan, sehingga karyawan kurang bersemangat. Selain itu dalam 
observasi juga ditemukan kurangnya kepedulian manajemen dalam mengakomodir aspirasi dan ide-ide dari para karyawan PT Astra Credit Companies.

diketahui jika stres kerja yang dirasakan oleh karyawan pada PT Astra Credit Companies Cabang Pondok Cabe terbilang tinggi dibuktikan dengan mayoritas hasil jawaban pada pra survey karyawan setuju dengan petanyaan yang diberikan oleh penulis. Pada pertanyaan nomor dua mayoritas karyawan kesulitan berfikir ketika dalam tekan pekerjaan yang berat. Selain itu karyawan juga sulit termotivasi bekerja apabila tugas pekerjaan tidak sesuai dengan kemampuan.

Selain beban kerja dan juga kebosanan akan keadaan dalam melakukan pekerjaan yang dapat menyebabkan stress kerja. Rotasi kerja juga dapat menjadi penyebab yang dapat mempengaruhi kinerja karyawan, hal tersebut yang dialami suatu perusahaan. Dan dihadapi oleh para karyawan.

Putar pekerjaan mendorong karyawan dapat mengoptimalkan potensial, menambah pengalaman dan pengetahuan, mengurangi kebosanan di perusahaan, memberi tahu karyawan tentang peluang peningkatan karir, dengan pekerjaan pemasaran, yang dinamis dan fleksibel, akan menjadi tantangan bagi karyawan.

Menurut Suryadi (2013:16), Putar adalah bagian dari manajemen kinerja, yang merupakan cara yang dapatkan hasil yang lebih untuk kelompok dan individu dengan membandingkan terhadap tujuan, standar, dan persyaratan kompetensi yang ditentukan. Mengetahui bagaimana stres karyawan dengan kinerja dan menilai banyak stres bagian dianggap efek dan mempromosikan pekerjaan karyawan mengupayakan kemampuan terbaik karyawan di tempat dia bekerja.

Pemberlakuan sistem rotasi kerja di PT Astra Credit Companies career mapping yang didasari oleh prinsip "right man in the right place". Penempatan karyawan secara berputar atau lebih dikenal rotasi dilakukan karena sesuai dengan kebutuhan perusahaan agar dapat menempatkan seseorang yang dapat mengembangkan perusahaan walaupun ditempatkan dimana saja.

Dengan pesatnya perkembangan bisnis di era globalisasi, persaingan antara industri ini menjadi tidak bias dihindari. Menghadapi persaingan ini, dun dikenal sebagai mengelola sumber daya manusianya dengan cara terbaik, yaitu memperhatikan investasi dan hasil sumber daya manusia. Mencari tahu beberapa sumber daya manusia dapat menghasilkan di Perusahaan kinerja yang baik untuk mengoptimalkan produk.

PT Astra Credit Companies adalah perusahaan pembiayaan. Didirikan 15 tahun lalu, perusahaan ini telah digunakan secara kompeten, misalnya, dalam bidang keuangan dan selama lebih dari 10 tahun. Perusahaan kredit PT Astra sedang berkembang dan akan mempromosikan perubahan dalam layanan, pemasaran . Sebagai unit 
bisnis yang dikelola secara profesional yang melayani layanan keuangan untuk komunitas offline dan online. Bekerja di bidang pemasaran tidak mudah karena tidak memerlukan inisiatif besar, inovasi, kreatif, bertanggung jawab, komitmen perusahaan, optimis dalam semangat, sehingga menyelesaikan masalah, Visi yang sangat terarah. Jika perlu untuk mencapai laba, sesuaikan dengan parameter yang digunakan untuk mengukur kinerja. Parameter ini dijelaskan menggunakan kompetensi dan evaluasi kinerja. Hasil penilaian kinerja karyawan pada PT Astra Credit Companies Cabang Pondok Cabe yang belum mencapai target yang di harapkan oleh perusahaan tentunya banyak faktor yang mempengaruhinya, salah satunya beban kerja dapat membuat karyawan stress dan menimbulkan dampak-dampak negatif terhadap karyawan. Hal ini dapat dilihat dari peran dan jam kerja yang berlebihan yang dialami oleh karyawan. Sebagian besar karyawan pulang hingga malam setiap hari atau apabila dihitung berdasarkan jam kerja karyawan yaitu 10-12 jam perhari. Selain pada itu hari Sabtu karyawan tetap bekerja meskipun jam kerjanya lebih singkat.

\section{B. Identifikasi Masalah}

1. Karena peran kerja yang berlebihan menimbilkan dampak stres pada karyawan PT Astra Credit Companies

2. Beban pekerjaan yang berlebihan membuat karyawan semakin tertekan dan sulit termotivasi bekerja apabila tugas pekerjaan tidak sesuai dengan kemampuan.

3. Dampak stres kerja dapat negatif dan positif.

4. Rotasi kerja yang cukup tinggi sebagai bagian dari carrier mapping yang justru tidak selalu disukai dan diharapkan oleh karyawan

5. Akibat rotasi kerja memberikan dua dampak ada yang positif dan negatif.

6. pemasaran PT Astra Credit Companies belum maksimal karena kinerja karyawan yang belum sesuai target.

7. Penilaian kinerja karyawan belum mencapai target yang sudah ditentukan oleh perusahaan.

\section{Hipotesis Penelitian}

1. Pengaruh stress kerja terhadap kinerja karyawan

Ho1: Diduga tidak terdapat pengaruh stress kerja terhadap kinerja karyawan.
$\mathrm{Ha}_{1}$ : Diduga terdapat pengaruh tres kerja terhadap kinerja karyawan

2. Pengaruh rotasi kerja terhadap kinerja karyawan.

Ho2: Diduga tidak terdapat pengaruh rotasi kerja terhadap kinerja karyawan.
$\mathrm{Ha}_{2}$ : Diduga terdapat pengaruh rotasi kerja terhadap kinerja karyawan.

3. Pengaruh stres kerja dan rotasi kerja secara simultan terhadap kinerja karyawan.

$\mathrm{Ho}_{3}$ : Diduga tidak terdapat pengaruh stres kerja dan 
rotasi kerja secara simultan terhadap kinerja karyawan.

$\mathrm{Ha}_{3}$ : Diduga terdapat pengaruh stres kerja dan rotasi kerja secara simultan terhadap kinerja karyawan.

\section{TINJAUAN PUSTAKA}

\section{A. Stress Kerja}

Menurut Mangkunegara (2013: 87), stres kerja adalah perasaan yang dirasakan karyawan kompilasi mereka bekerja. Stres tidak terjadi dengan cara yang sama, tetapi menyebabkan stres yang ditimbulkan oleh faktorfaktor yang mempengaruhi psikis seseorang dan peristiwa yang terjadi di luar kemampuannya sehingga ini telah memulihkan jiwanya. Fahmi (2014: 69) menekankan adalah suatu kondisi yang mendorong diri sendiri dan jiwa seseorang melampaui kemampuan, karena jika dia tetap tidak terselesaikan akan berpengaruh pada kesehatan fisiknya.

Sedangkan Luthan dalam Manurung (2011:8), Stress adalah suatu tanggapan dalam menyesuaikan diri yang dipengaruhi oleh perbedaan individu dan proses psikologis,

sebagai konsekuensi dari tindakan lingkungan, situasi atau peristiwa yang terlalu banyak mengadakan tuntutan psikologis dan fisik seseorang".

\section{B. Rotasi Kerja}

Menurut Nanda et, al (2014: 48) rotasi kerja adalah pemindahan karyawan dari satu bidang ke bidang lain dengan tingkat dan tanggung jawab yang sama tanpa mengubah gaji. Rotasi pekerjaan adalah hal umum yang dilakukan perusahaan atau agen untuk karyawan. Rotasi dilakukan untuk karyawan yang telah bekerja lama. Poin lain yang dikemukakan oleh Santoso dan Riyardi (2012: 27) adalah bahwa rotasi pekerjaan adalah alat untuk belajar, menyegarkan, dan mampu mencegah kebosanan dari pekerjaan mereka.

Menurut Robbins dalam Santoso dan Riyardi (2012:27) menjelaskan bahwa kekuatan rotasi kerja dapat mengurangi kebosanan dan meningkatkan motivasi dengan melakukan diversifikasi aktivitas karyawan. Rotasi pekerjaan dapat mengurangi jumlah monoton yang terjadi terus menerus, yang dapat menyebabkan kebosanan dan mengurangi kinerja karyawan.

\section{Kinerja Karyawan}

Riniwati (2011: 50) menyatakan bahwa fondasi sebenarnya dari sebuah organisasi adalah kinerja. Tanpa kinerja, semua bagian organisasi tidak akan mencapai tujuan mereka. Kinerja sangat dibutuhkan sebagai bahan evaluasi bagi atasan.

Kinerja adalah hasil dari kualitas dan kuantitas pekerjaan yang dicapai seorang karyawan dalam pelaksanaan tugasnya sesuai dengan tugas yang diberikan kepadanya. Mangkunegara (2016: 67).

Meskipun Eddy Sutrisno (2010: 172) menyimpulkan bahwa kinerja karyawan diukur dari segi kualitas, kuantitas, waktu kerja dan kolaborasi untuk mencapai tujuan 
yang ditetapkan oleh perusahaan.

\section{METODLOGI PENLITIAN}

Penelitian yang digunakan dalam penelitian Ini adalah metode asosiatif dengan pendekatan kuantitatif.

Adapun dalam penelitian ini, yang menjadi populasi adalah seluruh karyawan PT Astra Credit Companies sebanyak 65 orang.

Dalam penelitian ini subyeknya berjumlah kurang dari 100 maka menggunakan Sampel Jenuh sehingga sampel dalam penelitian ini berjumlah $\mathbf{6 5}$ responden/orang.

Penelitian ini membutuhkan data tentang persepsi karyawan tentang dampak stres kerja dan rotasi pekerjaan terhadap kinerja karyawan. Pengumpulan data dalam penelitian ini dilakukan dengan beberapa cara:

1. Kuesioner

Merupakan pernyatan responden melalui pemilihan pernyataan-pernyataan yang akan dijadikan salah satu sumber data dalam penelitian.

2. Observasi

Merupakan salah satu metoda dalam melakukan penelitian dengan cara pengamatan secara langsung.

3. Studi Pustaka

Ada metode pengumpulan data dengan membaca buku, literatur, jurnal, referensi untuk studi yang dilakukan dan studi sebelumnya.

Dalam kegiatan analisis data maka diperlukan cara atau metode analisis data sebagai berikut:

1. Analisis Kuantitatif

2. Uji Instrumen
a. Uji Validitas
b. Uji Reliabilitas

3. Uji Asumsi Klasik
a. Uji Normalitas
b. Uji Multikolinearitas
c. Uji Autokorelasi
d. Uji Heteroskedastisitas

4. Uji Hipotesis
a. Analisis
Koefisien
Korelasi
b. Analisis Koefisien
Determinasi
c. Uji Model (Uji Statistik t)
d. Uji Model (Uji Statistik F)
e. Persamaan Regresi Liniear Berganda

\section{HASIL DAN PEMBAHASAN}

Hasil Penelitian

Rangkuman Hasil Uji Validitas

\begin{tabular}{|c|c|c|c|c|}
\hline Variabel & Pertanyaan & Nilai rhitung & Nilai rtabel & Kriteria \\
\hline \multirow{10}{*}{\begin{tabular}{|l} 
Stres Kerja \\
(X1)
\end{tabular}} & SK 1 & 0,365 & 0.246 & Valid \\
\hline & SK 2 & 0,510 & 0.246 & Valid \\
\hline & SK 3 & 0,774 & 0.246 & Valid \\
\hline & SK 4 & 0,663 & 0.246 & Valid \\
\hline & SK 5 & 0,720 & 0.246 & Valid \\
\hline & SK 6 & 0,714 & 0.246 & Valid \\
\hline & SK 7 & 0,512 & 0.246 & Valid \\
\hline & SK 8 & 0,699 & 0.246 & Valid \\
\hline & SK 9 & 0,712 & 0.246 & Valid \\
\hline & SK10 & 0,604 & 0.246 & Valid \\
\hline \multirow{10}{*}{$\begin{array}{l}\text { Rotasi } \\
\text { Kerja } \\
(\mathrm{X} 2)\end{array}$} & RK 1 & 0,471 & 0.246 & Valid \\
\hline & RK 2 & 0,301 & 0.246 & Valid \\
\hline & RK 3 & 0,542 & 0.246 & Valid \\
\hline & RK 4 & 0,366 & 0.246 & Valid \\
\hline & RK 5 & 0,493 & 0.246 & Valid \\
\hline & RK 6 & 0,424 & 0.246 & Valid \\
\hline & RK 7 & 0,416 & 0.246 & Valid \\
\hline & RK 8 & 0,620 & 0.246 & Valid \\
\hline & RK 9 & 0,436 & 0.246 & Valid \\
\hline & RK10 & 0,572 & 0.246 & Valid \\
\hline \multirow{10}{*}{$\begin{array}{l}\text { Kinerja } \\
\text { Karyawan } \\
(\mathrm{Y})\end{array}$} & KK 1 & 0,312 & 0.246 & Valid \\
\hline & KK 2 & 0,580 & 0.246 & Valid \\
\hline & KK 3 & 0,560 & 0.246 & Valid \\
\hline & KK 4 & 0,449 & 0.246 & Valid \\
\hline & KK 5 & 0,449 & 0.246 & Valid \\
\hline & KK 6 & 0,331 & 0.246 & Valid \\
\hline & KK 7 & 0,428 & 0.246 & Valid \\
\hline & KK 8 & 0,402 & 0.246 & Valid \\
\hline & KK 9 & 0,395 & 0.246 & Valid \\
\hline & KK10 & 0,574 & 0.246 & Valid \\
\hline
\end{tabular}


Hasil Uji Reliabilitas

Rangkuman Uji Reliabilitas Data

\begin{tabular}{|l|l|l|l|}
\hline Variabel & $\begin{array}{l}\text { Cronbac } \\
\text { h's } \\
\text { Alpha }\end{array}$ & $\begin{array}{l}\text { rSta } \\
\text { ndar }\end{array}$ & $\begin{array}{l}\text { Keterang } \\
\text { an }\end{array}$ \\
\hline Stres Kerja (X1) & 0.883 & 0,60 & Reliabel \\
\hline Rotasi Kerja (X2) & 0.793 & 0,60 & Reliabel \\
\hline Kinerja Karyawan (Y) & 0.777 & 0,60 & Reliabel \\
\hline
\end{tabular}

Uji Asumsi Klasik

Uji Normalitas

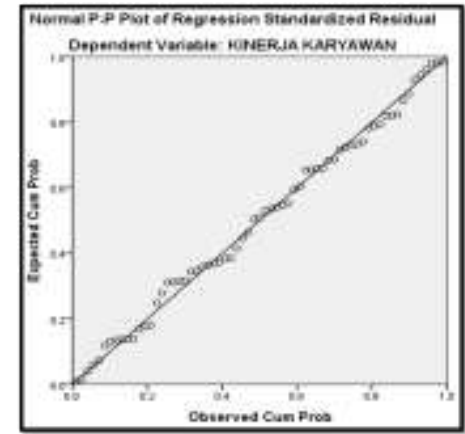

P-P Plot Uji Normalitas

Uji Multikolinearitas

Uji Multikolinearitas

\begin{tabular}{|c|c|c|c|c|c|}
\hline \multirow[t]{2}{*}{ Model } & \multicolumn{2}{|c|}{$\begin{array}{l}\text { Unstandardized } \\
\text { Coefficients } \\
\end{array}$} & \multirow{2}{*}{\begin{tabular}{|l} 
Standardized \\
Coefficients
\end{tabular}} & \multicolumn{2}{|c|}{ Collinearity Statistics } \\
\hline & $\mathrm{B}$ & Std. Error & & Tolerance & VIF \\
\hline (Constant) & 18.298 & 4.674 & & & \\
\hline $\begin{array}{l}\text { Stres Kerja } \\
\text { (X1) }\end{array}$ & .220 & .117 & .252 & & \\
\hline $\begin{array}{l}\text { Rotasi Kerja } \\
\text { (X2) }\end{array}$ & .625 & .122 & .660 & .568 & 1.759 \\
\hline
\end{tabular}

Uji Autokorelasi

Hasil Uji Autokorelasi

\begin{tabular}{|c|c|c|c|c|c|}
\hline \multicolumn{6}{|c|}{ Model Summaryb } \\
\hline $\begin{array}{l}\text { Mode } \\
1\end{array}$ & $\mathrm{R}$ & \begin{tabular}{|l} 
R \\
Square
\end{tabular} & $\begin{array}{l}\text { Adjustec } \\
\text { Square }\end{array}$ & $\begin{array}{l}\text { RStd. Error } \\
\text { of the } \\
\text { Estimate }\end{array}$ & $\begin{array}{l}\text { Durbin- } \\
\text { Watson }\end{array}$ \\
\hline 1 & $.647 a$ & .418 & .400 & 5.540 & 1.601 \\
\hline \multicolumn{6}{|c|}{$\begin{array}{l}\text { a. Predictors: (Constant), Rotasi Kerja (X2), Stres Kerja } \\
\text { (X3) } \\
\text { b. Dependent Variable: Kinerja (Y) }\end{array}$} \\
\hline
\end{tabular}

Uji Heteroskedastisitas

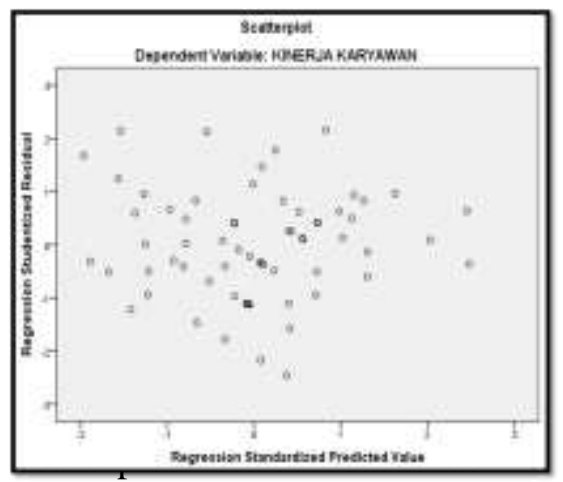

Pengujian Hipotesis

Uji Koefisien Korelasi (R)

Hasil Pengujian Koefisien Korelasi

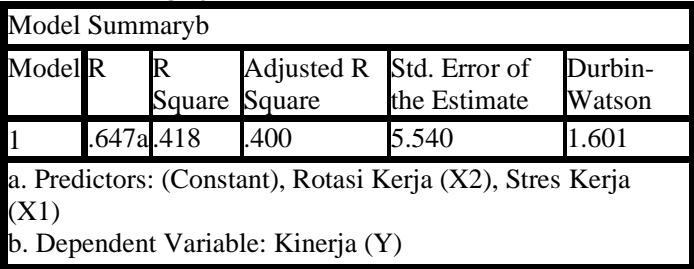

Berdasarkan hasil uji statistik pada tabel di atas diperoleh angka $(\mathrm{R})$ sebesar 0,647. Hal ini menunjukkan bahwa terjadi hubungan yang kuat antara pengaruh Stres Kerja dan Rotasi Kerja terhadap Kinerja Karyawan PT Astra Credit Companies Tangerang Selatan.

Uji Koefisien Determinasi

diketahui nilai $\mathrm{R}$ Square sebesar 0.418 sama dengan $41.8 \%$, berarti sumbangsih atau kontribusi variabel stres kerja dan rotasi kerja terhadap kinerja karyawan PT Astra Credit Companies Tangerang Selatan dapat di jelaskan oleh variabel bebas sebesar $41,8 \%$. Sedangkan sisanya $58,2 \%$ dapat dijelaskan oleh faktor-faktor selain yang diteliti dalam penelitian ini.

Uji Signifikansi (Uji t)

Hasil Uji Parsial (Uji t)

\begin{tabular}{|l|l|l|l|l|l|}
\hline \multirow{2}{*}{ Model } & \multicolumn{2}{|l|}{$\begin{array}{l}\text { Unstandardized } \\
\text { Coefficients }\end{array}$} & $\begin{array}{l}\text { Standardized } \\
\text { Coefficients }\end{array}$ & & \multirow{2}{*}{ Sig. } \\
\cline { 2 - 4 } & $\mathrm{B}$ & Std. Error & Beta & & \\
\hline (Constant) & 18.298 & 4.674 & & 3.915 & .000 \\
Stres Kerja (X1) & .220 & .117 & -.252 & -1.870 & .066 \\
$\begin{array}{l}\text { Rotasi Kerja } \\
\text { (X2) }\end{array}$ & .625 & .122 & .660 & 5.135 & .000 \\
\hline
\end{tabular}

Pengaruh Stres Kerja Terhadap Kinerja

Karyawan

Berdasarkan tabel diatas dapat diketahui variabel Stres Kerja memiliki nilai t hitung $-1,870>\mathrm{t}$ tabel 1,671. Hal ini berarti secara parsial Stres Kerja berpengaruh negatif dan tidak signifikan terhadap kinerja karyawan, dengan hasil signifikan yang menunjukkan nilai $0,066>0,05$. Hal ini menunjukan bahwa Ho ditolak dan $\mathrm{H} 1$ diterima, artinya variabel stres kerja secara parsial berpengaruh negatif dan tidak signifikan terhadap kinerja karyawan. Sehingga, jika nilai stres kerja turun maka kinerja karyawan akan meningkat. 
Pengaruh Rotasi Kerja Terhadap Kinerja Karyawan.

Berdasarkan tabel di atas dapat diketahui variabel Rotasi Kerja memiliki nilai $\mathrm{t}$ hitung 5,135 > t tabel 1,671 dengan nilai signifikan $0,000<0,05$. Hal ini menunjukkan bahwa Ho ditolak dan $\mathrm{H} 2$ diterima artinya variabel rotasi kerja secara parsial berpengaruh positif dan signifikan terhadap kinerja karyawan. Sehingga, jika nilai variabel rotasi kerja naik maka kinerja karyawan akan meningkat.

Uji Simultan (Uji F)

Hasil Uji Simultan (Uji F)

\begin{tabular}{|l|l|l|l|l|l|}
\hline ANOVAa & Sum of Squares & df & $\begin{array}{l}\text { Mean } \\
\text { Square }\end{array}$ & F & Sig. \\
\hline Model & 1369.314 & 2 & 684.657 & 22.307 & $.000 b$ \\
\hline Regression & 1902.932 & 62 & 30.692 & & \\
1 Residual & 3272.246 & 64 & & & \\
Total & a. Dependent Variable: Kinerja (Y) \\
b. Predictors: (Constant), Rotasi Kerja (X2), Stres Kerja (X1) \\
\hline
\end{tabular}

Tabel 4.15 di atas mengungkapkan bahwa nilai Fhitung adalah 22.307 dengan tingkat signifikansi 0.000. Sedangkan Ftabel pada tingkat kepercayaan $95 \%(\alpha=0.05)$ adalah 3.15. Berdasarkan kedua perhitungan statitik tersebut di mana Fhitung > Ftabel dan tingkat signifikansinya $(0.000)<0.05$ menunjukan bahwa pengaruh variabel bebas (stres kerja dan rotasi kerja) secara serempak adalah signifikan terhadap kinerja karyawan PT Astra Credit Companies Tangerang Selatan. Artinya variabel bebas yaitu stres kerja dan rotasi kerja secara bersama-sama (simultan) dalam mempengaruhi variabel terikat yaitu kinerja karyawan. Dengan kata lain hipotesis ketiga dalam penelitian ini terbukti di mana $\mathrm{Ho}$ ditolak dan $\mathrm{Ha}$ diterima.

Analisis Persamaan Regresi Linear

Berganda

Hasil Regresi Linier Berganda

\begin{tabular}{|l|l|l|l|l|l|}
\hline Model & \multicolumn{2}{|l|}{$\begin{array}{l}\text { Unstandardized } \\
\text { Coefficients }\end{array}$} & $\begin{array}{l}\text { Standardi } \\
\text { zed } \\
\text { Coefficie } \\
\text { nts }\end{array}$ & & Sig. \\
\cline { 2 - 4 } & $\mathrm{B}$ & $\begin{array}{l}\text { Std. } \\
\text { Error }\end{array}$ & Beta & & \\
\hline 1 (Constant) & $\mathbf{1 8 . 2 9 8}$ & 4.674 & & 3.915 & .000 \\
\hline
\end{tabular}

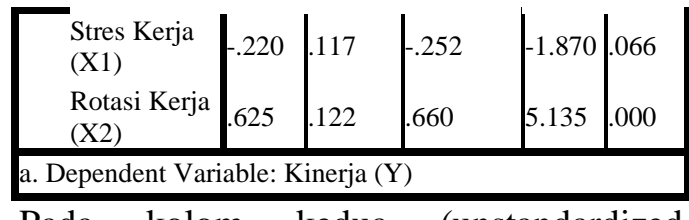

Pada kolom kedua (unstandardized Coefficients) bagian B diperoleh nilai b1 variabel stres kerja sebesar -0.220 nilai b2 dan variabel rotasi kerja sebesar 0.625 dan nilai konstanta (a) adalah 18.298 maka diperoleh persamaan regresi linier berganda sebagai berikut :

$\mathrm{Y}=\alpha-\beta 1 \mathrm{X} 1+\beta 2 \mathrm{X} 2+\varepsilon$

Di mana:

$\begin{array}{lll}\mathrm{Y} & = & \text { Kinerja Karyawan } \\ \mathrm{X} 1 & = & \text { Stres Kerja } \\ \mathrm{X} 2 & = & \text { Rotasi kerja } \\ \alpha & = & \text { Konstanta } \\ \beta 1, \beta 2= & \text { Koefisien regresi } \\ \varepsilon & = & \text { Standar eror } \\ \mathrm{Y} & =18.298-0.220 \mathrm{X} 1+ \\ 0.625 \mathrm{X} 2+\varepsilon & \end{array}$

Dari persamaan tersebut dapat digambarkan sebagai berikut:

Konstanta $(\alpha)=18.298$ ini menunjukkan bahwa jika variabel stres kerja dan rotasi kerja dianggap konstan maka variabel kinerja sudah mempunyai nilai sebesar 18.298 .

Koefisien $\beta 1(\mathrm{X} 1)=-0.220$ menunjukkan bahwa jika stres kerja mengalami penurunan dalam satu-satuan maka kinerjakaryawan akan meningkat dengan syarat variabel lain nilainya tetap.

Koefisien $\beta 2(\mathrm{X} 2)=0.625$ menunjukkan bahwa jika variabel rotasi kerja semakin baik maka kinerja karyawan akan meningkat sebesar satu satuan atau 0.625 dengan syarat variabel lain tetap.

\section{KESIMPULAN DAAN SARAN}

\section{A. Kesimpulaan}

1. Variabel Stres Kerja karyawan PT Astra Credit Companies Cabang Pondok Cabe mayoritas dijawab dengan sangat setuju sebesar 68,5\%, responden yang menjawab dengan kata setuju sebesar, $13,5 \%$, tidak setuju sebesar $12,5 \%$, sedangkan yang 
menjawab netral sebesar 5,5\%. Dengan demikian karyawan merespon sesuai dengan tingkat stres yang di rasakan atau termasuk ke dalam kriteria sangat tinggi dijawab oleh responden. Variabel stres kerja berpengaruh negatif dan tidak signifikan terhadap kinerja karyawan dengan nilai $t_{\text {hitung }}$ $1,870>t_{\text {tabel }} 1,671$ dan hasil signifikan yang menunjukkan nilai $0,066>0,05$. Hal ini berarti secara parsial Stres Kerja berpengaruh negatif dan tidak signifikan terhadap kinerja karyawan. Artinya penurunan kinerja pada karyawan PT Astra Credit Companies Cabang Pondok Cabe dapat dipengaruhi oleh meningkatnya stress kerja karyawan.

2. Variabel Rotasi kerja karyawan PT Astra Credit Companies Cabang Pondok Cabe mayoritas jawaban dari responden dengan kata sangat setuju sebesar 56,3\%, kata setuju sebesar $25,1 \%$, jawaban tidak setuju sebesar $15,5 \%$, yang menjawab dengan netral sebebsar 2,6\% dan jawaban terkecil yaitu pada kata sangat tidak setuju. Dengan demikian responden sangat setuju dengan rotasi kerja yang di lakukan oleh perusahaan. Variabel rotasi kerja berpengaruh positif dan signifikan terhadap kinerja karyawan dengan nilai $t_{\text {hitung }}$ $5,135>t_{\text {tabel }} 1,671$ dengan nilai signifikan $0,000<0,05$. Artinya peningkatan kinerja pada karyawan PT Astra Credit Companies Cabang Pondok Cabe dipengaruhi oleh rotasi kerja.

3. Pengaruh stres kerja dan rotasikerja terhadap kinerja karyawan berdasarkan perhitungan yang telah dilakukan diperoleh model persamaan regresi linier berganda $\mathrm{Y}=18.298$ $0.220 \mathrm{X} 1+0.625 \mathrm{X} 2+\varepsilon$. Artinya jika variabel stres kerja dan rotasi kerja dianggap konstan maka variabel kinerja sudah mempunyai nilai sebesar 18.298. Varibel stress kerja dan rotasi kerja secara simultan berpengaruh positif dan signifikan terhadap kinerja karyawan PT Astra Credit Companies Cabang Pondok Cabe. Hal ini dapat dilihat dari nilai $F_{\text {hitung }}>F_{\text {tabel }}$ yaitu $22,307>3,15$ dan nila sig $0,000<0,05$. Untuk kontribusi variabel bebas terhadap terikat didapat nilai $R$ Square sebesar 0,418, artinya kontribusi variabel bebas mempunyai kontribusi terhadap variabel terikat sebesar $41,8 \%$ dan sisahnya $58,2 \%$ adalah faktorfaktor lain yang tidak diteliti. Berdasarkan perhitungan koefisien korelasi (R) menunjukkan bahwa hubungan antar variabel stres kerja dan variabel rotasi kerja memiliki hubungan yang erat terhadap kinerja karyawan karyawan PT Astra Credit Companies Cabang Pondok Cabe dengan nilai koefisien korelasi 0,647 yang masuk pada kriteria hubungan yang 
kuat.

1. Untuk variabel stres kerja diharapkan kepada PT Astra Credit Companies Cabang Pondok Cabe untuk dapat memperhatikan peran yang diberikan kepada karyawan sehingga dapat bekerja sesuai dengan apa yang diharapkan oleh perusahaan. Begitu juga dengan beban kerja dan kejerlasan tugas yang diberikan kepada karyawan untuk lebih diperhatikan dengan tidak memberikan volume kerja yang besar diluar batas kemampuan karyawan sehingga setiap individu dapat bekerja dengan baik dan memudahkan peran karyawan dalam bekerja, sehingga karyawan merasa tidak tertekan dan tidak merasa stres oleh keadaan yang mereka terima.

2. Untuk variabel rotasi kerja diharapkan kepada manajemen PT Astra Credit Companies Cabang Pondok Cabe dapat mengatur bagaimana karyawan mau menerima ketika dipindah tugaskan ke divisi lain. Selain itu manajemen harus memperhatikan juga keberadaan karyawan pada suatu divisi sudah sesuia dengan kemampuan individu yang dimilikinya, sehingga mampu bekerja secara maksimal sesuai dengan apa yang menjadi harapan perusaan. Dengan adanya rotasi karyawang yang di rencanakan dengan baik akan dapat meningkatkan gairah para karyawan dalam melakun pekerjaan.

3. Untuk variabel kinerja karyawan diharapkan kepada manajemen PT Astra Credit Companies Cabang Pondok Cabe untuk bisa memberikan perhatian khsus kepada karyawan dalam mengatur waktu ketika banyak tugas yang diberikan. Sehingga target pekerjaan yang di tetapkan oleh pimpinan dapat dipenuhi dan diselesaikan dengan baik.

\section{DAFTAR PUSTAKA}

Dessler, Garry, 2006, Manajemen Sumber Daya Manusia, Jilid 2, Edisi Ke-7, Alih bahasa : Benyamin Mollan, Prehallindo, Jakarta.

Edy Sutrisno. 2010, Manajemen Sumber Daya Manusia.Jakarta: Kencana.

Flippo, Edwin B. 2011, Manajemen Personalia PT. Gelora Askara Pratma, Jakarta

Handoko, T. Hanny. (2010). Pengantar Manajemen. Yogyakarta: BPFE

Hasibuan, Malayu. 2013. "Organisasi dan Motivasi". Jakarta: Bumi Aksara.

Krisnaldy, K., Pasaribu, V. L. D., \& Senen, S. (2019). PENGARUH BUDAYA ORGANISASI, LINGKUNGAN KERJA DAN IKLIM TERHADAP MOTIVASI 


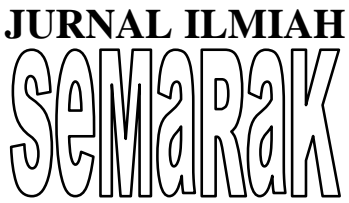

PEGAWAI

DAMPAKNYA

KEPUASAN

Semarak, 2(2).

Kreitner, Kinicki. 2011. Organizational

Behavior. New York: McGrawHill

Luthans, Fred. 2011. Organizational Behavior : An Evidence-Based Approach. New York: McGrawHill.

Mangkunegara, Anwar Prabu. 2016. Manajemen

DayaManusia

Bandung.

Manuaba,IAC.,IBagus,danIBGde.2010. IlmuKebidanan,PenyakitKandun gandanKBuntukPendidikanBidan .Edisikedua.Jakarta:EG

Moeheriono. 2012. "Pengukuran Kinerja Berbasis Kompetensi". Jakarta: Raja Grafindo Persada.

Munandar. 2010. Psikologi Industri dan Organisasi. Jakarta:Penerbit Universitas Indonesia (UI-pres).

Pasaribu, V. L. D., \& Krisnaldy, K. (2018). ANALISIS KEPUASAN JAMA'AH PADA KINERJA DEWAN KEMAKMURAN MASJID AL-HIDAYAH PERIODE TAHUN 2017. KREATIF: Jurnal Ilmiah Prodi Manajemen Universitas Pamulang, 6(4), 41-51.

Pasaribu, V. L. D., Krisnaldy, K., \& Warasto, H. N. (2020).
Pengaruh Gaya

Kepemimpinan, Disiplin Kerja

Dan Kompensasi Terhadap

Kinerja Pegawai (Studi kasus kelurahan Pisangan

Ciputat). Disrupsi Bisnis, 3(1).

Riniwati, Harsuko. 2011. "Mendongkrak Motivasi dan Kinerja: Pendekatan Pemberdayaan SDM". UB Press: Malang.

Rivai, Veithzal. 2013. Manajemen Sumber DayaManusia, Edisi kedua. Jakarta : Rajawali Pers

Robbins dalam Santoso dan Riyardi (2012:27

Sedarmayanti. 2011. Manajemen Sumber Daya Manusia, Reformasi Birokrasi dan Manajemen Pegawai Negeri Sipil (cetakan kelima). Bandung: PT Refika Aditama

Sondang P.Siagian. 2014, Manajemen Sumber Daya Manusia. Jakarta: PT Bumi Aksara.

Sugiyono. 2012. Memahami Penelitian Kualitatif'. Bandung ALFABETA

Suryadi Grimaldi, dkk, 2013, "Implementasi Web Service Untuk Mobile Commerce",Jurnal Ilmu Komputer dan Sistem Informasi Universitas Tarumanegara,hal.73-78.

Wijayanto,Dian.Pengantar Manajemen. Jakarta: GramediaPustakaUtama. 2012. 